\title{
Front Matter: Volume 10866
}

, "Front Matter: Volume 10866," Proc. SPIE 10866, Optogenetics and Optical Manipulation 2019, 1086601 (2 April 2019); doi: 10.1117/12.2531380

SPIE. Event: SPIE BiOS, 2019, San Francisco, California, United States 


\section{PROGRESS IN BIOMEDICAL OPTICS AND IMAGING}

\section{Optogenetics and Optical Manipulation 2019}

Samarendra K. Mohanty

E. Duco Jansen

Editors

2-3 February 2019

San Francisco, California, United States

Sponsored and Published by

SPIE 
The papers in this volume were part of the technical conference cited on the cover and title page. Papers were selected and subject to review by the editors and conference program committee. Some conference presentations may not be available for publication. Additional papers and presentation recordings may be available online in the SPIE Digital Library at SPIEDigitallibrary.org.

The papers reflect the work and thoughts of the authors and are published herein as submitted. The publisher is not responsible for the validity of the information or for any outcomes resulting from reliance thereon.

Please use the following format to cite material from these proceedings:

Author(s), "Title of Paper," in Optogenetics and Optical Manipulation 2019, edited by Samarendra K. Mohanty, E. Duco Jansen, Proceedings of SPIE Vol. 10866 (SPIE, Bellingham, WA, 2019) Seven-digit Article CID Number.

ISSN: 1605-7422

ISSN: 2410-9045 (electronic)

ISBN: 9781510623743

ISBN: 9781510623750 (electronic)

Published by

SPIE

P.O. Box 10, Bellingham, Washington 98227-0010 USA

Telephone +1 3606763290 (Pacific Time) · Fax +1 3606471445

SPIE.org

Copyright (C) 2019, Society of Photo-Optical Instrumentation Engineers.

Copying of material in this book for internal or personal use, or for the internal or personal use of specific clients, beyond the fair use provisions granted by the U.S. Copyright Law is authorized by SPIE subject to payment of copying fees. The Transactional Reporting Service base fee for this volume is $\$ 18.00$ per article (or portion thereof), which should be paid directly to the Copyright Clearance Center (CCC), 222 Rosewood Drive, Danvers, MA 01923. Payment may also be made electronically through CCC Online at copyright.com. Other copying for republication, resale, advertising or promotion, or any form of systematic or multiple reproduction of any material in this book is prohibited except with permission in writing from the publisher. The CCC fee code is 1605$7422 / 19 / \$ 18.00$.

Printed in the United States of America.

Publication of record for individual papers is online in the SPIE Digital Library.

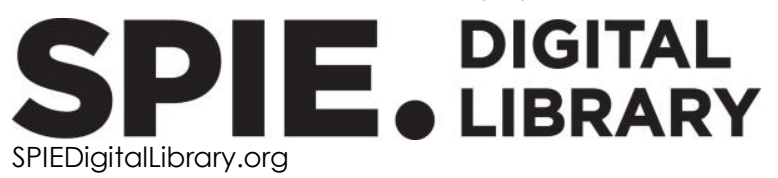

Paper Numbering: Proceedings of SPIE follow an e-First publication model. A unique citation identifier (CID) number is assigned to each article at the time of publication. Utilization of CIDs allows articles to be fully citable as soon as they are published online, and connects the same identifier to all online and print versions of the publication. SPIE uses a seven-digit CID article numbering system structured as follows:

- The first five digits correspond to the SPIE volume number.

- The last two digits indicate publication order within the volume using a Base 36 numbering system employing both numerals and letters. These two-number sets start with 00, 01, 02, 03, 04, 05, 06, 07, 08, 09, OA, OB ... OZ, followed by 10-1Z, 20-2Z, etc. The CID Number appears on each page of the manuscript. 


\title{
Contents
}

\author{
$\checkmark \quad$ Authors \\ vii Conference Committee
}

FUNCTIONAL IMAGING I

1086603 A bimodal bioluminescent $\mathrm{Ca}^{2+}$ indicator toward spatiotemporally scalable imaging (Invited Paper) [10866-1]

1086605 Optimized large-scale optogenetic interface for non-human primates [10866-3]

FUNCTIONAL IMAGING II

1086609 Optogenetic control of cytokinesis shows that polarized trafficking governs the process [10866-7]

ADVANCED STIMULATION I

$10866 \mathrm{OE} \quad$ Infrared block of $\mathrm{Na}^{+}$and $\mathrm{Ca}^{2+}$ spikes in in crayfish neuromuscular junction [10866-12]

ADVANCED STIMULATION II

10866 OK In vivo holographic photo-stimulation and two photon GCaMP6 imaging of vagus nerve axons using a GRIN lens integrated nerve cuff [10866-28] 
Proc. of SPIE Vol. 10866 1086601-4

\section{Downloaded From: https://www.spiedigitallibrary.org/conference-proceedings-of-spie on 26 Apr 2023
Terms of Use: https://www.spiedigitallibrary.org/terms-of-use}




\section{Authors}

Numbers in the index correspond to the last two digits of the seven-digit citation identifier (CID) article numbering system used in Proceedings of SPIE. The first five digits reflect the volume number. Base 36 numbering is employed for the last two digits and indicates the order of articles within the volume. Numbers start with 00, 01, 02, 03, 04, 05, 06, 07, 08, 09, OA, OB...0Z, followed by 10-1Z, 20-2Z, etc.

Caldwell, John H., OK

Castillo-Badillo, Jean A., 09

Chan, Jia Wen, 05

Farhana, Israt, 03

Fontaine, Arjun K., OK

Futia, Gregory L., OK

Gautam, N., 09

Gibson, Emily A., OK

Griggs, Devon J., 05

Harlalka, Suyash, 09

Khateeb, Karam, 05

Lin, Jen-Wei, OE

Littich, Samuel, OK

Matsuda, Tomoki, 03

McCullough, Connor, OK

Meshik, Xenia, 09

Nagai, Takeharu, 03

Ojemann, William K. S., 05

Philips, Stephen A., 05

Restrepo, Diego, OK

Sander, Michelle Y., OE

Suzuki, Kazushi, 03

Weir, Richard F., OK

Yazdan-Shahmorad, Azadeh, 05

Zhu, Xuedong, OE 
Proc. of SPIE Vol. 10866 1086601-6

Downloaded From: https://www.spiedigitallibrary.org/conference-proceedings-of-spie on 26 Apr 2023 Terms of Use: https://www.spiedigitallibrary.org/terms-of-use 


\title{
Conference Committee
}

\author{
Symposium Chairs
}

James G. Fujimoto, Massachusetts Institute of Technology (United States)

R. Rox Anderson, Wellman Center for Photomedicine, Massachusetts General Hospital (United States) and Harvard Medical School (United States)

Symposium Co-chairs

Jennifer Barton, The University of Arizona (United States)

Wolfgang Drexler, Medical University of Vienna (Austria)

Program Track Chairs

David A. Boas, Boston University (United States)

Elizabeth Hillman, Columbia University (United States)

Conference Chairs

Samarendra K. Mohanty, Nanoscope Technologies, LLC (United States)

E. Duco Jansen, Vanderbilt University (United States)

Conference Program Committee

Antoine Adamantidis, McGill University (Canada)

George J. Augustine, Duke-NUS Graduate Medical School (Singapore)

Klaus B. Gerwert, Ruhr-Universität Bochum (Germany)

Xue Han, Boston University (United States)

Elizabeth Hillman, Columbia University (United States)

Richard Kramer, University of California, Berkeley (United States)

Alfred L. Nuttall, Oregon Health \& Science University (United States)

Anna W. Roe, Zhejiang University (China)

Ulrich T. Schwarz, Technische Universität Chemnitz (Germany)

Shy Shoham, NYU Langone Health (United States) and Technion-Israel Institute of Technology (Israel)

John P. Welsh, University of Washington (United States)

Rafael Yuste, Columbia University (United States)

\section{Session Chairs}

1 Functional Imaging I

Samarendra K. Mohanty, Nanoscope Technologies, LLC (United States) 
2 Functional Imaging II

E. Duco Jansen, Vanderbilt University (United States)

3 Advanced Stimulation I

Sarmishtha Satpathy, Openwater (United States)

4 Advanced Stimulation II

Anna W. Roe, Zhejiang University (China)

5 Optical Manipulation I

Shy Shoham, NYU Langone Health (United States) and Technion-Israel Institute of Technology (Israel)

6 Optical Manipulation II

E. Duco Jansen, Vanderbilt University (United States) 